コントラスト特性を設討し䛦断能を向上した。本システ ムは被曝線量低減と共に，短時間撮影等の效果とも相侯 って総合的画質向上に有效である。

\section{3. スクリーンタイプマンモグラフィの粒状性の一因} 子

小西六写真工業K.K.

\section{○黑田 裉次}

スクリーンタイプマンモグラフィでバキュームパック を使用与ると，特有のモトルが発生し粒状性を著しく劣 化させる場合があった：このモトルはスクリーンの種類 によって形状が異り，フィルムの種類により発生の程度 に差加あった。

武作オルソフィルムを用いてモトルのメカニズムを検 討した結果，スクリーン表面の凸状部によるフィルムへ

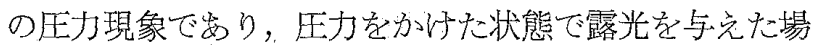
合にのみ発生することが解った。

対策として，压力の影響を受け難いつィルム構造を研 笲してその技術をタイプCに適用した結果，バキューム 時に発生するモトルを完全に除くことができた。

\section{座長集約}

演題89(誌)「センシトィータの安定化とその試作回路 について」クロネックスセンシトメータが電压ドロップ， リップル等の原因で不安定であり，このまを現像液管理 に使用すると写真濃度で $25 \%$ も変動が女るので，電源 安定装置を試作することにより，濃度偏差 $1 \%$ 以内とい う，極めて安定した性能が得られたとの発表である。こ れに対乙越ヶ谷市民病院，堤氏は，自己の経験乃ら，感 光材料，目現機等のハララ.ッキを考光た場合，濃度偏差 1 \%以内には納弯らないとし，別室でも本件に関する活発 な討議があった! センシトメータ自体の精度とそれを使 って管理した結果の間題は，分離して討論すべきであっ た点，座長として不手際であった．現像液管理，写真特 性検討の際，基本となる装置なるが故に，この精度向上 は重要な問題である。

演題90 (誌) 静岡県下[中部地区】に䄱ける使用力セッテ の密着性について,

言うまでもなく，カセッデ，増感紙とフィルムとの密 着性は，X線写真撮影の基本間題であり，この点を検討 せずに写真の画質，蘚鋭度を論議しても意味がない。こ の様な観点から，本問題をとり女げた静同支部中部地区 研究班の着眼とご努力に対し敬意を表したい，追加発言 にも专った如く，密着不良面積の大小出るにせよ，調 查対象カセッテの約 $50 \%$ に何等かの黑状があったとの結 果は大いに注目されるべき事項である.
演題91〜93は，いずれもスクリーンタイプマンモグラ フィに関する発表で，91(誌)は種々なシステムでの特性 を検討し，国産システムで充分マンモグラフィに適応し 得る。特にスクリーン,フィルム雨方を持っている專用 システムの力が叜定性女りと論じ，演題92(口)は，マン モグラフィ用スクリーンとして，希土類営光体 $\mathrm{Gd}_{2} \mathrm{O}_{2} \mathrm{~S}$ : Tb とオルソタイプ片面フィルムを組合せることによ り， $\mathrm{CaWO}_{4}$ 系の約 2 倍の感度が得られ，かつ診断上価 值める画貿を有守るものの開発が出来たことを発表した。 特にマンモグラフィの場合，微細な石灰化像の描出が必 要なために，綜合的粒状性を細かくすることに重点が拉 かれた。

一方この種の子のに用いられるフィルム结一般的通性 としてバキウムパック使用時に，特有の亡トルが発生し 易いが；演題93(口)では，この間題をとらえ，その原因 はスクリーン表面のフィルムへの圧力現象で岁るとし， 感材開発にあだりこの面に留意し，モトルの発生しな いフィルムを設計できたことが発表された。

スクリーソタイプマソモグラフィは，徒来のノースク リーンタイプにくらベ, 被懪線量低減に效果大なので, 今後は定性的実験とともに，多数の臨床データが発表さ れることを期待したい。

\section{管理-1被曝管理}

座長 後藤 勝正（荒尾市民病院）

\section{4. 被ばく軽减への方策（第 1 報）福島県における撮 影条件と被ばくの現況}

福島県立医科大学

○伊藤 陸郎・上西 稔・宮城 勝

斎藤 瑞男・関場 盛也

被ばく㪕減策については多くの報告が感り，医学会， 技師会で日钓告されているが，各施設で実施されている かは疑間である，福島県内の放射線技師の勤務する施設 での撮影条件と胸部撮影特の被ばく線量の状態を調査し 他県の報告と比較した，增感紙虫感度から中感度へ向 っている事が分る、胸部撮影の高任化とフィルタの使用 については蜜り考虑されていない、装犆容量加ら見る とかなり改善の余地をもっている，测定データ等以アン ケート集諳のをと各施設に戻して，拘束力をるって改善 策をこ5じる様にしないと技師自身が自己施設での現状 を把握し得ないでいる事存痛感した。

95. X線検査時の生殖腺被曝線量推定方法の試み 第 2 報

聖マリアンナ医科大学病院放射線部

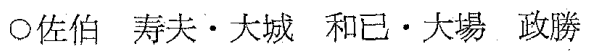

